\title{
FACTORS EXPLAINING THE ADOPTION OF RISK MANAGEMENT INSTRUMENTS IN MEDITERRANEAN IRRIGATED AGRICULTURE
}

\author{
$\underline{\text { José A. Gómez-Limón }}^{a *}$, Sandra M. Sánchez-Cañizares ${ }^{b}$ and M. Dolores Guerrero-Baena ${ }^{a}$
}

${ }^{a}$ WEARE-Water, Environmental and Agricultural Resources Economics Research Group, University of Cordoba, (jglimon@uco.es, dolores.guerrero@uco.es, Cordoba, Spain); ${ }^{b}$ Department of Business Organization, University of Cordoba, (sandra.sanchez@uco.es, Cordoba, Spain)

\begin{abstract}
Agriculture is highly impacted by different sources of risk. There is a wide variety of management instruments that farmers can use to cover these risks. The objective of this paper is to analyze the explanatory variables for the simultaneous adoption of a large set of risk management instruments. The main innovation is the methodological approach: first, we apply a hierarchical cluster analysis to identify the groups of instruments whose adoption is correlated; second, we use multivariate probit models to analyze the influence of different factors on the simultaneous adoption of the instruments included in each cluster. Explanatory variables capture farmers' socio-demographic features, perception of risks, risk aversion and subjective perception of past risk experience; farms' technical-economic characteristics; and perception of local-level climate change. The results show that there are significant differences in the variables influencing the adoption of the risk management instruments. The findings provide useful information to support the decision-making process for three main stakeholders: farmers (optimal choice over the joint use of instruments), providers of agricultural risk management instruments (e.g., the design of new combinations of risk management instruments better targeted to distinct profiles of farmers), and policymakers (policy strategies aiming to promote better risk management within the agricultural sector).
\end{abstract}

Keywords: Adoption decisions, Hierarchical cluster analysis, Multivariate probit, Risk perception, Risk preferences

\section{Introduction}

Agriculture is an economic activity characterized by its high exposure to risk [Hardaker et al. (2004)]; many different sources of risk may negatively affect farmers' income and well-being [OECD (2011)]. In this sense, the most widely-accepted classification of agricultural risks differentiates between: i) production risks, such as hails, frosts, or droughts; ii) market risks, arising from fluctuations in the market prices for inputs and/or outputs; iii) financial risks, particularly associated with the volatility of interest rates; iv) legal and institutional risks, related to changes in agricultural policies and regulations; and v) other risks, such as those linked to farmers' civil liability.

In this highly uncertain environment, farmers, as risk-averse economic agents [Just y Pope (2013)], usually respond by adopting a portfolio of different risk management instruments in order to reduce their exposure to risk and help stabilize their agricultural incomes [Velandia et al. (2009)]. These instruments are usually classified as follows [Meraner y Finger (2019)]: i) on-farm agricultural risk management instruments (technological optimization, good management practices, use of resistant seed varieties, and crop diversification); ii) on-farm non-agricultural risk management instruments (uptake of forward contracts, sales through cooperatives, and precautionary savings); and iii) off-farm risk management instruments (agricultural insurance, other insurance schemes, contribution to a private pension fund, off-farm employment, and off-farm investments).

A recurrent question raised within the literature is related to the factors that may influence farmers' adoption of risk management instruments [Duong et al. (2019)]. However, most research is based on the individual adoption of concrete risk management instruments [e.g., Asravor (2019)]. Only some studies have considered the simultaneous adoption of several risk management tools available to farmers, but all of them include a very small set of instruments in the analysis (only two or three) [e.g., Velandia et al. (2009); Lu et al. (2017)]. Thus, the main objective of this paper is to analyze the factors that may influence the simultaneous adoption of risk management instruments, considering the real set of such tools available to farmers and the possible relationships among them. The analysis considers factors related to farmers' sociodemographic variables, farms' technical-economic characteristics, subjective perception of risk, risk aversion, past risk experience, and farmers' perceptions about climate change. A Mediterranean-climate region in southern Spain, the irrigated agriculture in the province of Córdoba, has been used as a case study for the empirical research. 


\section{Material and methods}

\subsection{Case study, data collection, and sample description}

As it has been previously commented, the irrigated agriculture of the province of Córdoba (Spain) is used as a case study. This agricultural system is managed by a population of 3,369 farmers working 111,451 irrigated hectares. The main crop grown in this case study is olive ( $44.6 \%$ of the irrigated area), followed by cereals, oilseeds, and protein crops. The joint effect of the several sources of risk (mainly, production risks related to droughts and market risks derived from the volatility of crop prices) leads to relevant income losses for the farmers operating in the case study area. In fact, it is estimated that the number of farmers suffering from annual income losses above $30 \%$ in this agricultural system is more than 35\% [MAPA, (2019)], a share significantly over the European average [EC (2017)]. All of this justifies the choice of Córdoba as an interesting case study for this research.

In order to collect the data required for the empirical work, a survey of a representative sample of irrigated farmers from the case study was carried out. The selected farmers were interviewed face-to-face to complete a questionnaire structured in five parts: i) main characteristics of the farm; ii) farmers' subjective perception of the different sources of risk, as well as the data to calculate the level of individual farmers' risk aversion (CRRA); iii) farmers' past experiences regarding each source of agricultural risk and perception of climate change locally; iv) adoption of each of the 12 risk management instruments available to the irrigation farmers; and v) socio-demographic variables. A total of 204 completed and validated questionnaires were obtained.

The average farmer in the sample is 54.8 years old, has a low to medium educational level (two-thirds of the sample have completed secondary education) and farming activity is the main source of income $(62.4 \%$ of total income). On average, they manage an agricultural holding with 46.8 hectares with the following crop pattern: $41.2 \%$ of olive groves, $21.2 \%$ of other ligneous crops, $21.0 \%$ of cereals, oilseeds, and protein crops, $9.4 \%$ of other extensive herbaceous crops, and $7.2 \%$ of horticultural crops. They perceive market risks (average of $35.7 \%$ of total perceived risk) and production risks (average of $29.2 \%$ of total perceived risk) as the most relevant ones. Farmers in the sample are medium to high risk-averse and most of them agree that the impacts of climate change are occurring locally.

\subsection{Methods}

On the one hand, the farmers' perceptions regarding each source of agricultural risk were measured using the best-worst multicriteria decision-making method [Rezaei (2015)], allowing to estimate their relative importance as weights summing up to one. On the other hand, the level of individual farmers' risk aversion was measured by the constant relative risk aversion (CRRA) coefficient, elicited through the lottery-choice task method proposed by Eckel y Grossman (2008).

To analyze the factors explaining the simultaneous adoption of risk management instruments, a novel methodological approach was implemented. First, we applied the agglomerative hierarchical clustering (AHC) to identify the groups of 3-4 risk management instruments whose adoption was correlated. And second, the influence of exogenous factors on the simultaneous adoption of the instruments included in each cluster was modeled through multivariate probit (MVP) regression [Cappellari y Jenkins (2003)], a popular modeling approach applied to dichotomous correlated data to investigate interdependent strategy adoption decisions [e.g., Velandia et al. (2009)].

The general specification of the MVP regression can be expressed as:

$$
Y_{i j}^{*}=\beta_{i} X_{i j}+\varepsilon_{i j}
$$

where $Y_{i j}^{*}(j=1, \ldots, m)$ is the dichotomous variable related to the adoption of risk management instrument $\mathrm{j}$ by farmer $i(i=1, \ldots, n), X_{i j}$ is a $1 \times k$ vector of the observed factors that affect the decision to adopt risk management instrument $j$ by farmer $i$ (explanatory independent variables), $\beta_{i}$ is a $k \times 1$ vector of unknown coefficients to be estimated, and $\varepsilon_{i j}$ is the vector of unobserved error terms normally distributed with zero mean and constant variance.

\section{Results and discussion}

From the implementation of the clustering procedure, the 11 instruments considered (the use of good management practices was excluded as all the farmers declared to apply them) have been grouped into the following three clusters:

Cluster 1 "Instruments for permanent crops": Technological optimization, other insurance, sale through cooperatives, and precautionary savings. 
Cluster 2 "Instruments for annual crops": Resistant seed varieties, crop diversification, forward contracts, and crop insurance.

Cluster 3 "Off-farm instruments": Pension funds, off-farm investments, and off-farm employment. From the estimated MVP models for the instruments included in clusters 1 to 3, some interesting results were obtained. First, regarding farmers' socio-demographic variables it should be highlighted that older producers are less likely to choose precautionary savings (result also reported by Ullah et al. (2015)) and off-farm employment. These findings may be explained because older farmers have more family expenses (e.g., paying for the university education of their children), so they are not able to allocate financial resources to precautionary savings, as well as older farmers are less likely to find other employment [McNamara y Weiss (2005)]. The most educated farmers - those who have a university degree - are more likely to adopt crop insurance, pension funds, and off-farm employment. It is usually hypothesized that agricultural producers with higher education tend to adopt sophisticated risk management instruments [Velandia et al. (2009)], such as crop insurance, an idea that is confirmed in our findings. Farmers who live in rural areas prefer on-farm tools such as technological optimization, sale through cooperatives, or the use of resistant seed varieties (the proximity of producers to their farms allows them to manage these instruments more accurately), while producers who live in urban areas tend to rely more on the use of crop insurance. And, contrary to some previous evidence [Benjamin y Kimhi (2006)], larger families are more likely to adopt off-farm investments.

Second, concerning the farm's technical-economic characteristics, farm size is positively associated with crop diversification, as previously reported by Asravor (2019): as the farm size increases, crop diversification becomes more technically feasible. Farmers who obtain higher farm gross margins per hectare are more likely to use resistant seed varieties, as was also obtained in Khan et al. (2020). It is worth noting that farmers who obtain higher farm gross margins per hectare in the case study are those who cultivate vegetables (the most profitable crops), and they are better able to afford the higher cost of resistant seed varieties. A higher proportion of non-family labor over total farming labor encourages the adoption of crop diversification: non-family workers are, generally, more qualified than family ones, what allows to cope with the more complex tasks entailing crop diversification. The cultivated area of ligneous or permanent crops (olive and orange trees in the case study area) positively affects farmers' decision to adopt technological optimization, such as deficit irrigation programming or fertigation.

Third, about farmers' perception of risks, results suggest that the adoption of the pension funds instrument is positively influenced by the perception of production, market, and financial risks, and the use of forward contracts is positively affected by the perception of the first two types of risks. It may be deduced that farmers in our case study consider these two instruments very useful to cope with the main risks in this irrigated farming system, in both the long (pension funds) and the short term (contract farming).

Fourth, in relation to farmers' risk aversion, the more risk-averse farmers are more willing to adopt pension funds and less likely to implement off-farm investments. This outcome may be explained by the different levels of risk associated with the management of these two instruments: quite low for the former but much higher for the latter.

Fifth, from the results regarding subjective past experience, farmers who claimed to have suffered substantial losses due to production risks are more likely to adopt the use of forward contracts, but less likely to adopt crop insurance. This may imply that insured farmers have a less intense perception of the production risks, probably because they have been using crop insurance during the previous years and this instrument has satisfactorily covered the existing production risks. Past experiences related to market and financial risks are positively associated with some instruments, while farmers' perceptions of climate change are not positively associated with the use of risk management instruments. Likewise, HamiltonWebb et al. (2017) found in their study that concern about climate change was not a significant motivation for a risk management behavioral response.

\section{Conclusions}

The evidence of this study suggests that the first cluster of instruments ("instruments for permanent crops": technological optimization, sales through cooperatives, other insurance, and precautionary savings) is preferred by full-time irrigated farmers who grow permanent crops and live in rural areas. The second cluster of instruments ("instruments for annual crops": resistant seed varieties, crop diversification, forward contracts, and crop insurance) is the most suitable for full-time irrigated farmers growing annual crops (both extensive crops and vegetables). Finally, the third cluster comprises the more complex tools ("off farm instruments": pension funds, off-farm employment, and off-farm investments) requiring greater knowledge and skills, making them more suitable for those farmers with university education. Moreover, the adoption of these instruments is positively correlated with part-time farming since they are mainly implemented by farmers with significant non-farm income. 
The analysis carried out is relevant for farmers since it supports decision-making regarding the joint use of instruments for risk management based on their socioeconomic characteristics, the typology of their agricultural holdings, and their perception of the risks they bear. Outcomes are also valuable for firms providing risk-bearing services because results could lead to the design of new combinations of risk management instruments better targeted to distinct profiles of farmers. Finally, this study can support policymakers in the design of future policy strategies aiming to promote better risk management within the agricultural sector. On this matter, it is worth remarking that the valuable insights gained here could feed into the current debate regarding the reform of the European Common Agricultural Policy (CAP) for the next programming period 2021-2027, with a special focus on the most suitable risk management tools to address risks, crises and natural disasters that agriculture may face.

\section{References}

Asravor, R.K. (2019). "Farmers' risk preference and the adoption of risk management strategies in Northern Ghana". Journal of Environmental Planning and Management, 62(5): 881-900.

Benjamin, C. y Kimhi, A. (2006). "Farm work, off-farm work, and hired farm labour: estimating a discretechoice model of French farm couples' labour decisions". European Review of Agricultural Economics, 33(2): 149-171.

Cappellari, L. y Jenkins, S.P. (2003). "Multivariate probit regression using simulated maximum likelihood". The Stata Journal, 3(3): 278-294.

Duong, T.T., Brewer, T., Luck, J. y Zander, K. (2019). “A global review of farmers' perceptions of agricultural risks and risk management strategies". Agriculture, 9(1): 10.

EC (European Commission). (2017). Study on risk management schemes in EU agriculture. DG Agriculture and Rural Development, Brussels

Eckel, C.C. y Grossman, P.J. (2008). "Forecasting risk attitudes: an experimental study using actual and forecast gamble choices". Journal of Economic Behavior and Organization, 68(1): 1-17.

Hamilton-Webb, A., Manning, L., Naylor, R. y Conway, J. (2017). "The relationship between risk experience and risk response: a study of farmers and climate change". Journal of Risk Research, 20(11): 1379-1393.

Hardaker, J.B., Huirne, R.B.M., Anderson, J.R. y Lien, G. (2004). Coping With Risk in Agriculture. CABI, Wallingford, UK.

Just, R.E. y Pope, R.D. (2013). A Comprehensive Assessment of the Role of Risk in US Agriculture. Springer, Boston, USA.

Khan, I., Lei, H.D., Shah, I.A., Ali, I., Khan, I., Muhammad, I., . . Javed, T. (2020). "Farm households' risk perception, attitude and adaptation strategies in dealing with climate change: promise and perils from rural Pakistan". Land Use Policy, 91: 11.

Lu, W., Latif, A. y Ullah, R. (2017). "Simultaneous adoption of contract farming and off-farm diversification for managing agricultural risks: the case of flue-cured Virginia tobacco in Pakistan". Natural Hazards, 86(3): 1347-1361.

MAPA (Ministerio de Agricultura Pesca y Alimentación). (2019). Indicadores de resiliencia. Indicadores microeconómicos basado en pérdidas de renta. Ministerio de Agricultura Pesca y Alimentación (MAPA), Madrid.

McNamara, K.T. y Weiss, C. (2005). "Farm household income and on- and off-farm diversification". Journal of Agricultural and Applied Economics, 37(1): 37-48.

Meraner, M. y Finger, R. (2019). "Risk perceptions, preferences and management strategies: evidence from a case study using German livestock farmers". Journal of Risk Research, 22(1): 110-135.

OECD (Organisation for Economic Co-operation and Development). (2011). Managing Risk in Agriculture: Policy Assessment and Design. OECD Publishing, Paris.

Rezaei, J. (2015). "Best-worst multi-criteria decision-making method". Omega, 53: 49-57.

Ullah, R., Jourdain, D., Shivakoti, G.P. y Dhakal, S. (2015). "Managing catastrophic risks in agriculture: simultaneous adoption of diversification and precautionary savings". International Journal of Disaster Risk Reduction, 12: 268-277.

Velandia, M., Rejesus, R.M., Knight, T.O. y Sherrick, B.J. (2009). "Factors affecting farmers' utilization of agricultural risk management tools: the case of crop insurance, forward contracting, and spreading sales". Journal of Agricultural and Applied Economics, 41(1): 107-123. 